https://helda.helsinki.fi

\title{
Preventing crime against cultural and archaeological sites
}

\section{Thomas, Suzie}

Routledge

2020-04-15

Thomas , S \& Nicholas , L 2020 , Preventing crime against cultural and archaeological sites . in A Harkness (ed.), Rural Crime Prevention : Theory, Tactics and Techniques . Routledge, New York, pp. 249-260.

http://hdl.handle.net/10138/335841

acceptedVersion

Downloaded from Helda, University of Helsinki institutional repository.

This is an electronic reprint of the original article.

This reprint may differ from the original in pagination and typographic detail.

Please cite the original version. 
Thomas, S., and Nicholas, L. (2020) Preventing Crime against cultural and archaeological sites. In: A. Harkness (ed) Rural Crime Prevention, London: Routledge. 249-260.

\section{Preventing crime against cultural and archaeological sites Suzie Thomas and Louise E. Nicholas}

Heritage crime encompasses a wide range of acts that negatively affect the cultural historic environment - acts that break existing laws, but also those which are considered to be harmful, if not illegal. Examples of the former may be arson, theft and criminal damage; examples of the latter may include redevelopment of ancient cities, or the displacement of peoples with associated loss of their cultural heritage, including intangible cultural heritage. Definitions of heritage crime are therefore varied. It is clear that heritage crime affects not just buildings and artefacts, but also protected areas such as forests (for example, Ituri in the Democratic Republic of Congo), lakes (for example, Plitvice in Croatia) and coral reefs (for example, the Great Barrier Reef in Australia).

Heritage crime also affects a broader consideration of cultural heritage, such as the loss of songs, stories and traditional medicines resulting from the destruction of Indigenous groups' habitats through deforestation or mining (Mitten, 1997). Heritage crime may range from a relatively low level of damage to the complete destruction of assets as a result of terrorist activities and war crimes: in 2017, Ahmad al-Faqi al-Mahdi was the first person to be convicted of heritage crime as a war crime in the International Criminal Court after the 2012 destruction of protected sites in Timbuktu.

For pragmatic reasons, the focus of this chapter is narrowed to damage resulting from an illegal act against physical heritage assets in rural areas. While it touches upon intangible heritage, the main focus remains tangible heritage sites. The chapter considers some examples of rural heritage crime around the world and how crime prevention may be utilised in the heritage context. It critically assesses some successes and failures of heritage crime prevention to date, reflects on what lessons can usefully be drawn from current knowledge and looks to the need for greater information-sharing in the future.

\section{Heritage crime around the world}

Whilst heritage crimes can occur in both rural and urban settings, the focus of this chapter is on rural heritage crimes in particular. The range of types of heritage crimes within our parameters are diverse, and thus we highlight here just a few illustrative examples.

In the Nordic region, particularly in Norway, rural churches have been especially vulnerable to arson, with ideological elements seemingly at play. Williams (2012) has discussed the 1992 burning of a twelfth-century stave church at Fantoft in Bergen, Norway, as a form of protest by black metal enthusiasts about the Christianisation of what was apparently previously a pagan site. Although the church has since been restored, it has become a site of pilgrimage and an important place for the history of the black metal genre in Norway.

Other Nordic countries have suffered from different architecture-related crimes. In Finland, a nation famed for innovative design and architecture, structures by iconic architects such as Alvar 
Aalto have experienced relatively many instances of theft. This has included the theft of door handles and other small, easily removed objects from buildings, which - while listed as historic buildings - lack effective security measures. Aalto's buildings affected by this phenomenon include the Vuokenniska church in the municipality of Imatra on the border with Russia, which has lost several door handles to opportunists over the years. These thefts often go undetected until someone notices that the handle is gone. Design specialists in Finland speculate that these small architectural features are particularly appealing to thieves, partly because it is so easy to unscrew and remove them undetected (thus the opportunity level is high), but also because the market price for vintage Finnish design objects is much higher outside of Finland where the items automatically become rarer and thus more desirable to collectors (Thomas, 2014).

Maritime heritage also suffers from heritage crime incidents, most notably illegal salvage of shipwrecks. Salvage activity - whether legal or not - is itself a controversial practice, with many maritime archaeologists and other cultural heritage specialists critical of the practice (see, for example, Hosty, Hunter \& Adhityatama, 2018 on the commercial salvaging and subsequent protection of the Australian ship HMAS Perth in Indonesian territorial waters). A news report on the apparently prevalent illegal salvage of such Second World War shipwrecks in Asian seas highlighted not only the prevalence of the problem but also the status of many wrecks as war graves, and thus that salvage also disturbs the final resting places of many servicemen (Holmes, Ulmanu \& Roberts, 2017).

Archaeological site looting remains a particularly well-known and well documented form of heritage crime, sometimes obfuscating that other offences and actions also cause harm to cultural heritage. Decades' worth of scholars and journalists have noted both the archaeological impact of looting, and also its feed into international markets and organised crime networks (see, for example, Meyer, 1973; Davis, 2011): the problem seems to show no sign of abating.

On a usually smaller, localised scale, and without known connections to wider crime networks, illegal metal detecting is an issue that can affect cultural heritage in various rural areas, especially in Europe. In certain jurisdictions, metal detecting is permitted provided that protected sites are avoided and finds are reported to the relevant authorities. However, even in countries where the hobby is not against the law, illegal behaviours can still occur. In the United Kingdom, illegal metal detecting has acquired the nickname 'nighthawking', and law-abiding hobbyist metal detecting enthusiasts have been quick to distance themselves as "real' detector users" from the lawbreakers (Wilson \& Harrison, 2013).

In some instances, the scale of the illegal detecting, the status of the objects found and the level of public outcry has been sufficient to effect a change in national legislation. This was the case with the discovery of the Derrynaflan Hoard - a cache of medieval ecclesiastical metal ware - in rural Ireland by a father and son in 1980. Although the site of the discovery was partially protected, the finders were entitled to a monetary reward for their discovery under Irish law at the time. However, a widely publicised dispute over the amount of the award led to a public backlash against the finders, and the Derrynaflan affair is credited with leading to the outlawing of metal detecting in Ireland (Kelly, 1994).

In England, there have been several well-documented and publicised incidents of nighthawking. One case in 1983 in the village of Wanborough, Surrey, is also widely credited with leading to the 
enactment of England and Wales's current Treasure Act 1996 which, while not making metal detecting illegal, tightened up definitions and regulations concerning the activity. The RomanoBritish site yielded unknown numbers of artefacts such as Iron Age and Roman coins, and temple regalia such as sceptres and headdresses. Many objects remain un-retrieved from the market, and so the loss of archaeological knowledge about this site is incalculable (Thomas, 2009).

A significant challenge for some is to understand that much metal detecting happens legally and thus is not a heritage crime, although debates continue concerning the extent to which the hobby still represents harm. Jurisdictions vary concerning the extent to which non-professional activity such as metal detecting is permissible, but in countries such as the United Kingdom, Denmark, the Netherlands, Estonia and New Zealand, it is permitted to metal detect. In some cases, as with the last two countries mentioned, metal detecting may require an official permit. In most cases, metal detecting is forbidden on known archaeological sites, while some countries operate schemes to encourage legal metal detectorists to report their discoveries accurately. The benefits of this collaborative approach can be considerable and demonstrate the value of engaging with different stakeholders. In England and Wales, where the Portable Antiquities Scheme has been recording chance finds made by metal detectorists and others since 1997, over 455 research projects, including some 95 doctorates, have used data generated through the Scheme (Lewis, 2016).

Another form of heritage crime that evokes deep debate is graffiti. Increasingly, graffiti is coming to be understood as an important form of alternative expression (Moreau \& Alderman, 2011), as a source of archaeological and historical information in its own right (Champion, 2015) and as a more recent cultural layer to heritage sites (Merrill, 2011). However, concerns also continue as to the impact of graffiti on historic properties and monuments. Ancient rock art sites in South Africa, for example, have long been vulnerable to graffiti, which undoubtedly causes serious damage to these often remote sites (Smith, 2006). In the Spanish city of Granada, studies of public art from a conservation perspective have also identified graffiti and other forms of vandalism as a significant risk (Márquez, 2017).

In countries with Indigenous populations, another significant challenge is ensuring the protection and appropriate treatment of Indigenous cultural heritage, which may be both tangible and intangible. Economic developments can leave Indigenous cultural heritage vulnerable to damage or complete destruction, and legal protection is not always forthcoming. Rolfe and Windle (2003) have noted that in Australia, while "spectacular" Aboriginal heritage sites are often protected, landowners and developers may fail to recognise smaller everyday sites as heritage, leaving them with no protection. In Sápmi - the traditional homelands of the Indigenous Sámi people spanning across northern Norway, Sweden, Finland and parts of Russia's Murmansk Oblast - expansion of mining is seriously threatening traditional Sámi lifeways, while legislation in each respective country varies in the extent to which it protects Indigenous rights (Koivurova et al., 2015).

\section{Crime prevention in the heritage context}

Once there is a local consensus that an activity or damage needs to be reduced via an intervention, attention can turn to established knowledge about crime prevention practices. Particular care needs to be taken around the application of crime prevention to the historic environment, as it is possible for well meaning activities to be detrimental rather than effective. Examples from recent years include a fence introduced to prevent damage by off-road vehicles 
being installed across the middle of a protected monument; and wiring for closed circuit television (CCTV) being run across the fabric of historic buildings.

There are added complications within rural areas, as measures that may be cost efficient within an urban setting are not guaranteed to transfer well into a more isolated community. We need to consider the context, mechanisms and outcomes (Pawson \& Tilley, 1997) in advance of introducing new schemes. When discussing crime prevention, we often contemplate measures such as the introduction of CCTV and security guards. However, these are often too expensive for heritage asset owners, managers and tenants and are often not effective in the rural heritage context because blanket coverage is not realistic. If we consider the expected mechanisms by which CCTV and security guards are expected to reduce crime, it may be that we expect the offender's perceived risk of apprehension to be greater.

Without blanket coverage, this is not a realistic expectation. Research in other settings has shown that the outcome of increased formal security and CCTV is not particularly effective, in the latter case unless it is narrowly targeted and actively monitored (cf. Felson \& Boba, 2010; Piza, Welsh, Farrington \& Thomas, 2018) which increases costs beyond the reach of most. We therefore have to think more innovatively and draw on lower-cost measures to protect our rural historic environments.

Grove and Pease (2014) developed an outline guide to some such measures, based on Cornish and Clarke's (2003) 25 techniques of situational crime prevention, and a number of these are detailed in this chapter. Crime is not random, and it is impossible to protect all places at all times. Therefore, we must consider developing appropriate risk assessments to determine where to target crime prevention measures for the greatest chance of success. These systems are not infallible, and nothing supersedes local knowledge and understanding, but they can provide a framework within which to have discussions about relative priorities, particularly when informed by good-quality data.

A commonly used framework within crime prevention is that of CRAVED (Clarke, 1999) which identifies items which are likely to be stolen: those which are concealable, removable, available, valuable, enjoyable and disposable. Whilst initially developed for use in generic acquisitive crime, the framework has been adapted to more specific situations such as livestock theft in Malawi (Sidebottom, 2013); parrot poaching in Bolivia (Pires \& Clarke, 2012) and the antiquities market (Grove, Daubney \& Booth, 2018).

To help identify likely sites, the framework HOPPER (history, open, protection, publicity, evasion and repeat victimisation) was developed as a guide to "the characteristics of a site that is likely to be targeted by offenders looking for antiquities" (Grove et al., 2018, p. 1042) and is usable alongside existing risk assessment proformas to assess risk more specifically in the heritage context. HOPPER is briefly outlined in Table 16.1.

As data about heritage crime remains generally of such low quality and availability (see Grove, Thomas \& Daubney, 2018), it is vital that informal sources such as local communities, voluntary groups and neighbours are consulted as they may have important information that is not captured via any formal routes. This might include sightings of suspicious activity, times at which a site 
seems busy, or identifying which assets are most important to the local community and so warrant greater consideration of protection.

\section{Heritage crime prevention: successes and failures}

There have been a variety of efforts to prevent heritage crime at rural sites, with a range of successes and failures. Many of these attempts are undocumented: they are carried out by small voluntary groups, individuals with a responsibility for managing a site, or a community who cares for a village or church. In short, there is likely to be much we do not know about within rural heritage crime prevention, but there are some examples to draw from. In addition, we can learn from other forms of rural crime prevention, as outlined elsewhere in this book, and apply this knowledge to the heritage context. Let us focus now, predominantly, on suggestions with a lower cost, in the hope that these may be adaptable to more environments than changes to infrastructure and additional employees.

\section{Signage}

A simple and relatively low-cost measure to reduce crime is the introduction of signs around protected assets. Publicity of crime prevention measures has been shown to reduce crime even before any crime prevention activity takes place (Johnson \& Bowers, 2003). A number of approaches can be taken, including the advertisement of other crime prevention measures such as membership of a watch scheme (see later in this chapter), posting of rules and information or the requesting of assistance.

Table 16.1 An outline of the HOPPER framework

History If there is a history of CRAVED artefacts being present or discovered at the site, this may act as an indicator to potential offenders that there is a potential reward to targeting the asset.

Open Where the site has easy physical public access, and/or is well documented in the public domain, it is more likely to be in an offender's "awareness space" (Brantingham \& Brantingham, 1993).

Protection Protected status can act as a beacon for offenders by indicating that there may be further unknown finds on the site.

Publicity If a site is known about or receiving new attention from official or clandestine sources, this increased awareness may also increase risk to the site. However, it should be noted that there are times that publicity may be used as a form of crime prevention in itself, for example by advertising that newly discovered archaeological sites have been thoroughly searched and all finds removed.

Evasion Where there are several known access routes to a site, it may be easier to escape apprehension and such sites may therefore be more likely to be targeted by offenders due to the lower risk involved.

Repeat victimisation It remains the case that the best predictor of future victimisation is past victimisation, so if the site has been a target previously, this should act as a flag to introduce new crime prevention measures - even if these are only temporary (such as increased patrols for a few weeks).

Advertising other crime prevention measures is a common occurrence, both when they are physical and more esoteric in nature. There is some evidence that publicity around additional 
preventive measures is in itself sufficient to deter criminal activity (Laycock, 1991). That is, advertising that there is forensic marking or extra police patrols on site has a reductive effect on crime, even where no such measures exist. However, it is likely that some criminals are equally aware of this as a tactic!

Spending time considering the wording of signs at heritage assets is worthwhile. Simpler messages may be more effective than, for example, posting all the bylaws or other local legislation that apply to a site, as people are more likely to read briefer signs. One experiment took place at the Petrified Forest in Arizona in the United States where signs read: "Many past visitors have removed petrified wood from the Park, changing the natural state of the Petrified Forest".

These signs were then replaced by ones which read: "Please don't remove the petrified wood from the Park, in order to preserve the natural state of the Petrified Forest" (Cialdini, 2003, p. 107). The latter message resulted in a much lower number of thefts. The reason is simply that the former normalised the criminal activity, whereas the latter made it clear that normal behaviour was to preserve the site. Such 'behavioural nudges' are well known in crime prevention and are particularly useful in heritage crime prevention as they require relatively little investment.

Requesting compliance may not be an effective measure in extremely rural locations, but where a heritage asset exists in a village, at a tourist attraction or alongside a transport route, it can be useful to provide a brief description of behaviour that should be reported to the authorities or a private phone number or email address. This could be a short-term measure during a higher risk time of an archaeological excavation or building repairs, to request that locals report activity on site outside of set times, or a longer-term measure such as asking visitors to report suspected crime or incidents to a ranger or the police.

\section{Rumours of cursed objects}

An option that Grove and Pease (2014) posited was the use of rumours of particular objects or sites having curses attached to them. This may work best where many earlier rumours of curses connected to sites, especially ancient tombs, in part originate. Whilst at first consideration this may seem outlandish, in fact we have seen some successes in stolen objects being returned to heritage assets after their new 'owners' have been convinced that bad luck has followed them as a result of their pilfering.

At the Petrified Forest in Arizona, Thompson and Orr highlight the petrified wood that was returned with accompanying notes on the reasons such as "nothing but bad trouble" (Thompson \& Orr, 2014, p. 50) and "this rock was taken without knowledge of the curse. Sorry" (Thompson \& Orr, 2014, p. 103). Likewise, Bodie State Historic Park in California has a book on display in their museum with letters, which accompanied returned items, some of which were believed to have curses attached. Ideally, objects would not be taken in the first place - the returned petrified wood, for example, remains in a pile by the entrance of the park as it would be impossible to return it to the (now unknown) original context. However, it may be that similar rumours act as a deterrent and result in fewer thefts.

\section{Forensic marking with traceable liquids}


A commonly used approach to heritage metal theft in England is the use of forensic marking techniques. A forensic marking technique is a unique trace substance, invisible to the naked eye, which identifies a marked item as belonging to a specific site or individual. Sometimes, as in the case of the War Memorials Trust partnership with SmartWater in England, this is carried out at no cost to the heritage organisation. In other cases, there may be a one-off or annual charge, although in some instances these may be alleviated by reduced insurance premiums.

Throughout the United Kingdom, traceable liquid property marking is an increasingly popular option. The logic is that by making items traceable back to the source, links between an offender and crime scene can be confirmed and therefore prosecutions are more likely. However, the role of such products in prevention is less clear cut: there have been mixed assessments, with offender interviews suggesting little deterrent effect of property marking (Wright, Logie \& Decker, 1995), whilst at least one assessment of an intensive program of forensic marking has shown a degree of success in domestic burglary (Raphael, 2015). Caution is suggested around the use of forensic marking when considering cost-effective measures.

\section{Neighbourhood Watch schemes}

There are a number of voluntary groups (such as Church Watch) in England that work closely with a local police force to share information about crimes affecting heritage: these watch schemes are organised under similar principles to more ubiquitous Neighbourhood Watch schemes. This is particularly important in relation to repeat victimisation, where not only might another offence happen shortly after an initial offence, but nearby and similar properties are also at heightened risk (cf Bowers \& Johnson, 2005). In England, this has been a particular problem for rural churches, many of which have had lead stolen from their roofs.

The rationale of Neighbourhood Watch and similar initiatives is that heightened awareness allows for greater preparedness. A systematic review of Neighbourhood Watch scheme evaluations suggests that whilst further research is needed, Neighbourhood Watch is effective at reducing crime (Bennett, Holloway \& Farrington, 2006). It is therefore likely that where high levels of engagement and collaboration can be encouraged, a Heritage Watch scheme could be a costeffective approach to heritage crime reduction. In rural areas, such as the county of Rutland in England, this has been enhanced by the development of a mobile phone app which provides even greater information sharing amongst rural communities, as well as facilitating easy reporting of suspicious activity and criminal behaviour. Leicestershire Police were the first police force in the United Kingdom to introduce a team of heritage crime volunteers to coordinate information sharing, carry out risk assessments and provide information and advice, and plans exist to expand owing to the demand for their support.

\section{Volunteers}

Volunteers have also been used to good effect more generally at heritage sites. There are opportunities to tap into the passion and enthusiasm for heritage extant within volunteer groups to help divert potential offenders away from criminal activity. Using volunteers as a part of citizen science projects - community archaeology, for example - can increase 'ownership' and participation at rural sites. This may also engage potential offenders in more legitimate 
expressions of their interest. Likewise, volunteer-led groups may lead exploration of remote sites, ensuring that damage does not occur whilst also providing access.

We should also consider the mechanisms by which projects of this ilk may succeed, to guard against possible adverse effects - for example, of raising awareness of access points and potential targets for theft. More broadly, encouraging use of a site if it is publicly accessible has many benefits. Some examples may be community classes in heritage buildings; regular baby and toddler meet-ups; special events for home education groups and schools; provision of open space for youth activities and sport; or social retirement groups. Many of these activities could raise enough revenue to be cost neutral, particularly when led by volunteers. In terms of crime prevention possibilities, having a broader user base increases the 'eyes on the street' (Jacobs, 1961) and shows ownership of a space (Newman, 1972), each of which reduces opportunities for

offending through increasing the perception of risk. However, again noting the special situation of heritage sites, measures should also ensure that there are not detrimental consequences such as accelerated erosion, which could affect the conservation of a site through increased usage.

\section{Conclusion}

Heritage crime is still an emerging field of research and in rural settings has particular needs and situations attached to them. Sites may be more vulnerable than in urban spaces owing to the smaller footfall and greater isolation from potential witnesses, while some solutions which seem practical in the city - such as CCTV and other surveillance - may be impossible in the countryside.

However, four important points can be helpful for limiting and preventing rural crime against cultural and archaeological sites:

1 Use whatever networks can be accessed. This may include Watch initiatives or social media networks

2 Learn from others' experiences. There are best practices to be found, and some approaches may be more effective than others depending on the type of heritage; the literature on heritage crime is growing constantly

3 Prioritise sites. If resources are stretched, it may be important to give priority to more vulnerable sites, for example sites which have fallen prey to repeat victimisation; recall the HOPPER principles 4 Share successes and failures. These can be difficult to evaluate at times, but just as we can learn from other experiences, so too can our own experiences help inform further heritage crime prevention

There is more to be done in the field of heritage crime research, and with new findings will come a deeper understanding of effective preventative measures.

\section{References}

Bennett, T., Holloway, K. \& Farrington, D. P. (2006). Does neighborhood watch reduce crime? A systematic review and meta-analysis. Journal of Experimental Criminology, 2(4), 437-458.

Bowers, K. \& Johnson, S. (2005). Domestic burglary repeats and space-time clusters: The dimensions of risk. European Journal of Criminology, 2(1), 67-92. 
Brantingham, P. L. \& Brantingham, P. J. (1993). Nodes, paths and edges: Considerations on the complexity of crime and the physical environment. Journal of Environmental Psychology, 13(1), 328.

Champion, M. (2015). Medieval graffiti: The lost voices of England's churches. London: Ebury Press.

Cialdini, R. B. (2003). Crafting normative messages to protect the environment. Current Directions in Psychological Science, 12(4), 105-109.

Clarke, R. (1999). Hot products: Understanding, anticipating and reducing demand for stolen goods, Police Research Series Paper 112. London: Home Office Policing and Reducing Crime Unit.

Cornish, D. B. \& Clarke, R. V. (2003). Opportunities, precipitators and criminal decisions: A reply to Wortley's critique of situational crime prevention. Crime Prevention Studies, 16, 41-96.

Davis, T. (2011). Supply and demand: Exposing the illicit trade in Cambodian antiquities through a study of Sotheby's auction house. Crime, Law and Social Change, 56(2), 155-174.

Felson, M. \& Boba, R. (2010). Crime and everyday life (4th ed.). Thousand Oaks, California: Sage Publications.

Grove, L., Daubney, A. \& Booth, A. (2018). Identifying sites at risk from illicit metal detecting: From CRAVED to HOPPER. International Journal of Heritage Studies, 24(10), 1038-1052.

Grove, L. \& Pease, K. (2014). A situational approach to heritage crime prevention. In L. Grove \& S. Thomas (Eds.), Heritage crime: Progress, prospects and prevention (pp. 107-127). Basingstoke: Palgrave Macmillan.

Grove, L., Thomas, S. \& Daubney, A. (2018). Fool's gold? A critical assessment of sources of data on heritage crime. Disaster Prevention Management, 29(1), 10-21.

Holmes, O., Ulmanu, M. \& Roberts, S. (2017, 3 November). The world's biggest grave robbery: Asia's disappearing WWII shipwrecks. The Guardian. Retrieved from www.theguardian.com/world/ng-interactive/2017/nov/03/worlds-biggest-graverobbery-asiasdisappearing-ww2-shipwrecks

Hosty, K., Hunter, J. \& Adhityatama, S. (2018). Death by a thousand cuts: An archaeological assessment of souveniring and salvage on the Australian cruiser HMAS Perth (I). International Journal of Nautical Archaeology, 42(2), 281-299.

Jacobs, J. (1961). The death and life of great American cities. New York: Vintage.

Johnson, S. D. \& Bowers, K. J. (2003). Opportunity is in the eye of the beholder: The role of publicity in crime prevention. Criminology and Public Policy, 2(3), 497-524. 
Kelly, E. (1994). Protecting Ireland's archaeological heritage. International Journal of Cultural Property, 3(2), 213-226.

Koivurova, T., Masloboev, V., Hossain, K., Nygaard, V., Petrétei, A. \& Vinogradova, S. (2015). Legal protection of Sami traditional livelihoods from the adverse impacts of mining: A comparison of the level of protection enjoyed by Sami in their four home states. Arctic Review, 6(1), 11-51.

Laycock, G. (1991). Operation identification, or the power of publicity? Security Journal, 2(2), 6772.

Lewis, M. (2016). A detectorist's utopia? Archaeology and metal-detecting in England and Wales. Open Archaeology, 2(1), 127-139.

Márquez, M. C. B. (2017). Conservation of the contemporary public sculptures of Granada: Protecting the city's heritage. Ge-conservación/conservação, 1(11), 134-140.

Merrill, S. O. C. (2011). Graffiti at heritage places: Vandalism as cultural significance or conservation sacrilege? Time and Mind, 4(1), 59-75.

Meyer, K. E. (1973). The plundered past. New York: Atheneum.

Mitten, L. (1997). The human cost of deforestation. Peace Review, 9(4), 549-553.

Moreau, T. \& Alderman, D. H. (2011). Graffiti hurts and the eradication of alternative landscape expression. Geographical Review, 101(1), 106-124.

Newman, O. (1972). Defensible space. New York: Palgrave Macmillan.

Pawson, R. \& Tilley, N. (1997). Realistic evaluation. Thousand Oaks, California: Sage Publications.

Pires, S. \& Clarke, R. (2012). Are parrots craved? An analysis of parrot poaching in Mexico. Journal of Research in Crime and Delinquency, 49(1), 122-146.

Piza, E. L., Welsh, B. C., Farrington, D. P. \& Thomas, A. L. (2018). CCTV and crime prevention: A new systematic review and meta-analysis. Stockholm: Swedish National Council for Crime Prevention.

Raphael, I. (2015). Cooling hot property? An assessment of the impact of property marking on residential burglary crime reduction, crime displacement or diffusion of benefits and public confidence (Doctoral thesis). University of Portsmouth, Portsmouth UK.

Rolfe, J. \& Windle, J. (2003). Valuing the protection of Aboriginal cultural heritage sites. Economic Record, 79(special issue), S85-S95.

Sidebottom, A. (2013). On the application of CRAVED to livestock theft in Malawi. International Journal of Comparative and Applied Criminal Justice, 37(3), 195-212. 
Smith, B. (2006). Rock art tourism in southern Africa: Problems, possibilities, and poverty relief. In N. Agnew \& J. Bridgland (Eds.), Of the past, for the future. Integrating archaeology and conservation (pp. 322-330). Los Angeles, California: Getty Conservation Institute.

Thomas, S. (2009). Wanborough revisited: The rights and wrongs of treasure trove law in England and Wales. In S. Thomas \& P. G. Stone (Eds.), Metal detecting and archaeology (pp. 153-166). Woodbridge: The Boydell Press.

Thomas, S. (2014). Vulnerable by design: Theft and Finnish architecture. The Historic Environment: Policy and Practice, 5(3), 231-244.

Thompson, R. \& Orr, P. (2014). Bad luck, hot rocks. Los Angeles, California: The Ice Plant.

Williams, T. J. T. (2012). A blaze in the northern sky: Black metal and crimes against culture. Public Archaeology, 11(2), 59-72.

Wilson, P. \& Harrison, M. (2013). Three years on from 'The Nighthawking Survey': Innovations in heritage protection. Internet Archaeology, 33. https://doi.org/10.11141/ia.33.7

Wright, R., Logie, R. H. \& Decker, S. H. (1995). Criminal expertise and offender decision making: An experimental study of the target selection process in residential burglary. Journal of Research in Crime and Delinquency, 32(1), 39-53. 